\title{
ELEMENTE VAN REVOLUSIE
}

Lt Kdr E.M. Meyers*

The prerequisites for revolution can be divided into categories, according to the author of the article below. The most important categories are provocation, united public opinion, hope, a strong leader element and low morale. Examples are quoted of countries in which revolutions came to pass and the purpose of the article is to draw the attention of the reader to a certain pattern of occurrences and circumstances applicable to any country in which a revolutionary situation exists or has existed in the past.

\section{Inleiding}

In die huidige tydsgewrig word baie publisiteit aan revolusionêre oorlogvoering gegee deur die media en akademiese geskrifte sowel as deur indiepte studies wat in militêre kringe daaroor uitgebring word.

Revolusionêre oorlogvoering kan net behoorlik begryp word as die klassieke model van revolusie nagegaan word. Hoewel revolusies uiteenlopend is wat plek, tyd, metodes en soort revolusie betref, is daar wesenlik ooreenkomste wanneer oorsake en gevolge nagegaan word.

Die metodes wat in die Franse Revolusie gebruik is, verskil duidelik van dié wat in die Sjinese en Kubaanse revolusies toegepas is. Tog is daar onderliggende beginsels van ooreenstemming, bv elk van dié revolusies is op ' $n$ mite of ideologie gebou wat gebruik is as regverdiging vir die omverwerping van die regeringsbestel.

Die saambindende faktor in moderne revolusies is die feit dat revolusionêres behep is met ' $n$ voorafbepaalde taktiek en spesifieke patroon waarvolgens revolusie gevoer moet word.

In sommige gevalle verloor revolusionêres egter die onderliggende beginsels wat nodig is vir die welslae van ' $n$ revolusie uit die oog. Die militêre faktor is belangrik as ' $n$ bepaler van die welslae al dan nie van revolusie, hoewel sosio-ekonomiese en ideologiese faktore wegbereiders vir revolusie is.

Vir die doel van dié studie is etlike modelle geselekteer omdat hierdie revolusies hoogtepunte was in die evolusie van revolusionêre konflik.

Nog 'n rede waarom opnuut gelet moet word op revolusie as fenomeen, is dat die wêreld in die teken van 'n totale revolusie staan soos Alvin Toffler in sy Future Shock en Third Wave dit behandel as die 'super-industriële revolusie'. Aan die beskouings van Toffler word daar in die loop van die artikel aandag gegee.

Die term revolusie was oorspronklik van toepassing op die omwenteling van die wiel van verandering deur een volkome draai. Om hierdie rede is ' $n$ vroeë toepassing op die politiek verbind aan die sikliese beskouing van die geskiedenis. ${ }^{1}$

\section{Wat is Revolusie?}

Revolusie is nie sinoniem met ò terrorisme òf insurgensie òf guerillaoorlogvoering. Dit is nie revolusionêre oorlogvoering nie, hoewel enige of almal hiervan elemente van revolusie kan wees. Revolusies kan selfs in die afwesigheid van oorloë of geweld plaasvind. Ter stawing hiervan is die Iraanse Revolusie van 1979 waar daar nie oorlog of burgeroorlog was nie hoogtens openbare geweldpleging.

Revolusies hoef nie polities van aard te wees nie. Die Industiële Revolusie in Engeland in die agtiende en negentiende eeue of selfs die bekende Renaissance wat ook bekend is as die Intellektuele Revolusie, is voorbeelde in dié verband. Volgens Le Bon het ware revolusies waardeur die lot van volkere verander is, oor die algemeen so stadig plaasgevind dat historici nie hul oorspronge kon uitwys nie. ${ }^{2}$

\section{Toepassingsterreine}

Bell noem die volgende gebruike of toepassingsterreine vir die begrip revolusie, naamlik dat die geskiedenis weer opnuut moet begin; as sosiale verandering; as ' $n$ metafoor van 'siekte' in dié sin dat revolusies 'n soort koors, waansin, herstel of terugval is; en as gewelddadige omverwerping van een sosiale klas deur 'n ander. Sommige skrywers definieer revolusie 
weer as die verwesenliking van sekere waardes en doelstellinge aangesien dit onder die vaandel van vryheid en vooruitgang gevoer word. ${ }^{3}$

Revolusies is ook as 'interne oorlog' beskou. Eckstein, die bekendsteller van dié begrip, definieer dit as 'any resort to violence within a political order to change its constitution, rulers or policies' ${ }^{4}$ Interne oorlog is dus polities gemotiveer.

Die spektrum van toepassingsterreine kan dus as volg saamgevat word: polities, militêr, ekonomies, sosiaal (of laasgenoemde twee dikwels as sosio-ekonomies), godsdienstig, tegnologies, ens. Alvin Toffler, 'n Amerikaanse sosioloog, beweer bv dat die wêreld vasgevang is in ' $n$ 'superindustriële revolusie'. ${ }^{5}$

\section{(i) Polities}

Hoewel Locke erken het dat revolusies kan plaasvind as gevolg van ambisie, groepe, ens, was hy van mening dat die verantwoordelikheid vir ' $n$ revolusionêre toestand amper altyd by die regering berus het. Mense het in opstand gekom omdat regeerders die vertroue van die ganse volk geskok het. ${ }^{6}$ In dié trant beweer Le Bon: 'It has been very justly said that governments are not overthrown, but commit suicide. ${ }^{7}$

In die werk Politics of Violece word daar volstaan met Peter Calvert se definisie, naamlik: 'Revolutions are forcible interventions, either to replace governments or to change the processes of government. ${ }^{18}$

Revolusie volgens Pettee vind plaas wanneer die staat se algehele mag doeltreffend gedaag word en hou dan aan totdat ' $n$ monopolie van mag heringestel is. ${ }^{9}$

Hierdie mening sluit aan by Chalmers Johnson se bekende definisie wat beweer revolusie is die aanvaarding van geweld met die doel om verandering teweeg te bring. ${ }^{10}$

Die element van geweld begin dus al hoe meer uitkristaliseer as onontbeerlike voorvereiste vir 'n geslaagde revolusie. Op grond hiervan beweer Le Bon dat dit voor die handliggend is dat revolusies nog nooit plaasgevind het en nooit sal plaasvind nie behalwe met die hulp van 'n belangrike deel van die leër. ${ }^{11}$
In dié trant beweer Mao Tse-tung dat die hoogste vorm van revolusie die magsoorname deur gewapende geweld en die beslegting van die saak deur oorlog is. ${ }^{12}$

\section{(ii) Ekonomies}

Die invloed wat ekonomiese faktore op die ontstaan van revolusies het, het uiteenlopende menings van revolusionêre denkers tot gevolg gehad.

Marx en Engels het ' $n$ eie teorie van revolusie opgestel wat daarop neerkom dat toenemende degradasie (of verslegting) van die industriële werkende klas uiteindelik die punt van wanhoop en onafwendbare opstand sou bereik. ${ }^{13}$

In teenstelling hiermee het Trotsky opgemerk dat as armoede en onderdrukking sou bydra tot die bespoediging van die revolusie, sou die laer klasse byna altyd in opstand wees. ${ }^{14}$

Tog het Marx ook beweer dat ' $n$ verbetering in die werkers se ekonomiese toestand, wat nie met die pas van die groeiende kapitalistiese welvaart tred hou nie, sosiale spanning en wydverspreide onrus tot gevolg het. ${ }^{15}$

De Tocqville op sy beurt meen dat sodra die ekonomiese las van 'n onderdrukte volk verlig word, 'n uitkomkans vir die volk uit sy finansiële moeras gesuggereer word en rebellie uitbreek. 'Evils which are patiently endured when they seem inevitable become intolerable when once the idea of escape from them is suggested. ${ }^{116}$

Davies kom tot die gevolgtrekking dat revolusies die maklikste plaasvind indien 'n periode van objektiewe ekonomiese en sosiale vooruitgang gevolg word deur 'n kort periode van skielike terugkeer. ${ }^{17}$

Herstel van 'n ernstige ekonomiese ontwrigting kan ook daarvoor verantwoordelik wees dat die stoom van die drukpot van rebellie afblaas. ${ }^{18}$

\section{(iii) Sosiaal}

Gottschalk definieer revolusie in terme van 'n populêre beweging waardeur betekenisvolle verandering in die struktuur van ' $n$ samelewing bewerkstellig word. ${ }^{19}$ In dieselfde trant beskou Chalmers Johnson revolusie as ' $n$ vorm van verandering binne die sosiale 
stelsel. Hy merk op dat revolusie as 'n tipe sosiale verandering die spandabelrigste, duurste, laaste keuse moet wees; maar ook die kragtigste en daarom altyd die verkieslikste as laaste uitweg vir die mens was. ${ }^{20}$

Die sosiale faktor word weer uitgelig wanneer Davies beweer dat politieke stabiliteit van die bui of geestelike instelling van ' $n$ samelewing afhang. Die voorsiening van gegewe hoeveelhede voedsel, vryheid of gelykheid sal nie so maklik revolusie veroorsaak as wat 'n ontevrede gemoed die gevolg daarvan sal wees nie. ${ }^{21}$

(iv) Intellektueel

Momboisse beweer dat ' $n$ revolusionêre toestand self nie revolusie veroorsaak nie. 'There must also be an organized force capable and willing to exploit the opportunity, indeed willing to take up arms to achieve power.' Hy gaan verder deur te spesifiseer dat revolusies minderheidsbewegings is. ${ }^{22}$

Beals sluit by hierdie mening aan deur sy stelling dat die gemene deler van alle revolusies die feit is dat hulle deur militante minderhede begin word. ${ }^{23}$

In sy bespreking van oorsake van revolusies beweer Louis Gottschalk dat intellektueles 'n groot rol speel, aangesien hulle help om die algemene bewustheid van ontevredenheid te bewerkstellig, as mede daardie verenigde openbare mening wat noodsaaklik vir ' $n$ effektiewe eis om revolusionêre verandering. ${ }^{24}$

(v) Tydsfaktor

Tyd was nog altyd ' $n$ belangrike faktor sover as wat revolusies en revolusionêre oorlogvoering aangaan. Mao Tse-tung, soos Marx, het dit sterk benadruk dat ' $n$ revolusie alleenlik kan slaag indien die tyd reg is. ${ }^{25}$

Die Latyns-Amerikaanse bevryder, Simon Bolivar, het gesê dat ' $n$ revolusie nie gemaak kon word nie, maar wanneer die tyd ryp was, sou dit plaasvind en as dit eers begin het, kon geen mag dit stop nie. Dié mening is ook deur Lenin nagehou. ${ }^{26}$

Die Meksikaanse hervormer Farias het beweer dat daar geen slot sterk genoeg was om die vooruitgang van die wêreld te keer nie. Tog kan die vooruitgang waarvan hier gepraat word, bevraagteken word, aangesien dit nie ' $n$ uitgemaakte saak is dat alle revolusies voordelig of dat alle verandering gewens is nie.

\section{Revolusies}

$\mathrm{Na}$ hierdie teoretiese inleiding word ' $n$ aantal revolusies behandel wat prototipe revolusies genoem kan word. ' $n$ Kort beskouing oor elk word gegee en faktore wat uiteenlopend is, sowel as dié wat gemeenskaplik is, word dan bepaal. Raymond Momboisse bepaal vier faktore in sy 'Blueprint of Revolution' wat, as hulle gelyktydig plaasvind, 'n revolusionêre situasie tot gevolg sou hê: eerstens ' $n$ krisis in die regerende klas wat nie langer kan voortgaan soos in die verlede nie; tweedens ' $n$ abnormale verslegting in ekonomiese toestande van die onderdrukte klasse; derdens gretigheid van die massas om tot aksie oor te gaan en vierdens ' $n$ morele en materiële disintegrasie van die leër en polisie en dus daarmee die gewapende magte. ${ }^{28}$

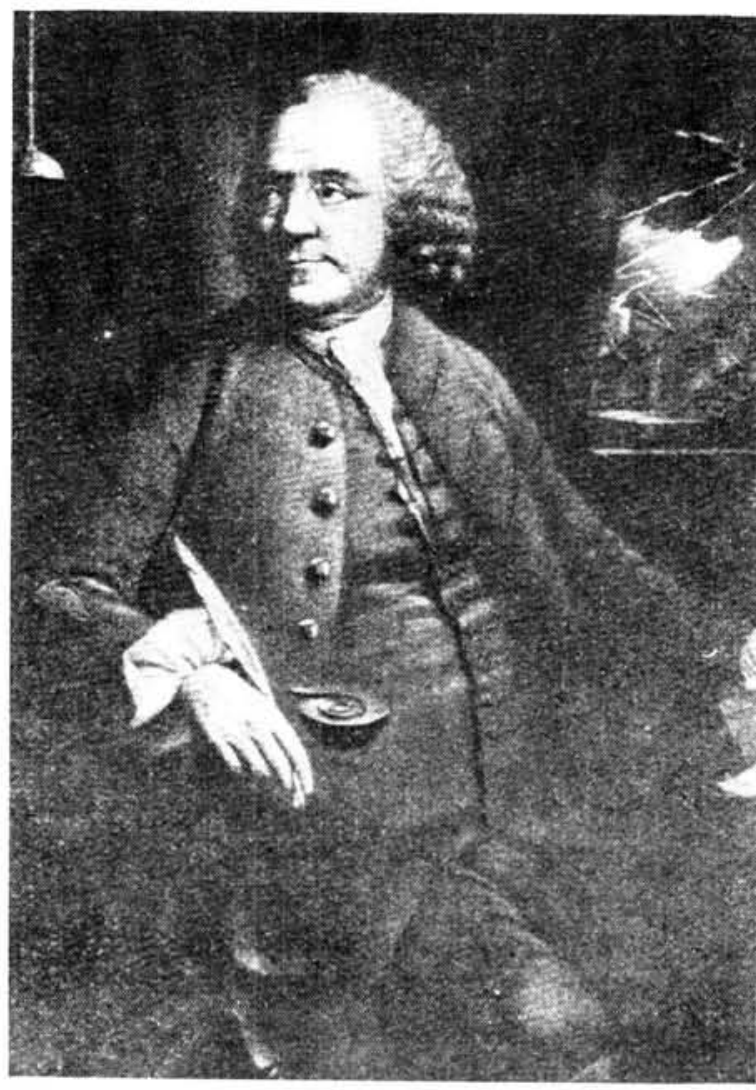

Hoewel die Amerikaanse Revolusie nie 'n direkte invloed gehad het op die Franse Revolusie nie, het die denke van Amerikaanse revolusionêre soos Benjamin Franklin tog wel 'n rol gespee 


\section{Die Franse Revolusie}

Hoewel die Amerikaanse Revolusie nie soseer ' $n$ direkte invloed op ander revolusies gehad het nie, was dit volgens Beals tog die grootvader van al die ander revolusies en is die era van revolusies daardeur ingelui. Frankryk het self die Amerikaanse kolonies bygestaan in hul vryheidstryd teen Engeland en is deur die denke van die Amerikaanse revolusionêre soos Franklin en Jefferson sowel as die filosoof Paine beïnvloed. Selfs die Fransman Lafayette het ook aan die Amerikaanse oorlog deelgeneem. ${ }^{29}$

In die Franse Revolusie van 1789 het soveel faktore so duidelik ' $n$ rol gespeel daarom word dit ook eerste bespreek en breedweg in groepe verdeel.

\section{Politieke Oorsake}

Brenton wys daarop dat die regeringsmasjienerie ondoeltreffend was. ${ }^{30}$ Frankryk was feitlik 'n absolute monargie met bykans al die mag in die hande van die koning wat oor die sogenaamde goddelike reg van konings beskik het. Op grond hiervan het Lodewyk XIV beweer dat hyself die staat is. ${ }^{31}$ Tog was die monargie in Frankryk nie meer baie sterk nie. By die hof wat die middelpunt van alle dinge was, het ' $n$ groot massa politieke aspirante en volgelinge saamgedrom wat byna almal van die bevoorregte klasse af gekom het. ${ }^{32}$

Afgesien van die koning was die enigste ander regeringsliggaam die State-Generaal, 'n soort parlement wat egter in onbruik verval het. Die opgevoede landsburgers kon geen effektiewe inspraak in die regering gee nie en was dus effektief uitgesluit van landsbestuur en daarmee van offisiële poste aan die hoof van die leër, vloot en diplomatieke diens. ${ }^{33}$

Le Bon beweer dat die Franse Revolusie as doel die vervanging van die mag van die adel of ou elite met dié van die bourgeoisie of nuwe elite gehad het. $^{34}$

Die feit dat die Franse Revolusie ' $n$ bourgeoisie revolusie is, word deur Alexander Gerschekron as ' $n$ historiese landmerk op die pad van feodalisme na kapitalisme beskou. ${ }^{35}$

\section{Sosio-Ekonomiese Oorsake}

Hoewel die volgende twee onderafdelings as een behandel kan word, naamlik die sosioekonomiese oorsake, verkies die skrywer om die maatskaplike en die ekonomiese aspekte apart te bespreek in die geval van die Franse Revolusie.

(a) Maatskaplik

Volgens George Rudé was dit slegs in Frankryk waar daar 'n revolusie in 1789 plaasgevind het wat nie net bedoel was om regerings- en politieke instellings omver te werp nie, maar om die sosiale bestel self te ontwortel en te verander. Geleerdes wil dit hê dat die Russiese Revolusie, nes die Franse Revolusie ook 'n sosiale of klassebasis gehad het. ${ }^{36}$

Die 'ancien-regime' het die verdeling van klasse as een van sy bronne van krag beskou en die verdeling tussen die drie stande is ongenaakbaar gehou, aldus Le Bon. Hy beskou dit as die belangrikste oorsaak van haat wat deur die feodale stelsel veroorsaak is, ${ }^{37}$ aangesien die klasse indeling die kriterium was vir die voorregte waarop elkeen geregtig was. Lede van die derde stand is ontneem van alle voorregte en van hulle is al die belastings gevorder. Wat sake vererger het, is dat daar geen vooruitsig vir ' $n$ evolusionêre oplossing van die situasie was nie. Hoewel die State-Generaal wel byeengeroep kon word, het dit nie konstitusioneel oor die mag beskik om enigiets aan die politieke of maatskaplike lot van die bevolking te doen nie. ${ }^{38}$

Die feit dat Lefebre die Franse Revolusie se boere-opstand as een van die mees uitstaande kenmerke van die revolusie beskou, is net een kant van die prentjie, aangesien die 1789-revolusie ' $n$ bourgeoisie- eerder as ' $n$ boereopstand was. $^{39}$ Tog is daar oorsake wat ekonomies-landboukundig verantwoord kan word.

\section{(b) Ekonomiese oorsake}

Die ekonomiese posisie van die Derde Stand het in die twee dekades voor die Revolusie merkbaar en aansielik versleg en boere is buitensporig swaar belas. Die geld wat Frankryk in die Amerikaanse Revolusie ingesteek het, was meer as wat die bankrot Franse kroon kon bekostig. Die luukse Franse hof het op sigself ' $n$ twaalfde van die land se inkomste ingesluk. Verder was die belastinstelsel belaglik oneffektief aangesien die adel, die geestelikes en die kroon wat drie vyfdes 
van die grond besit het, so te se geen belasting betaal nie.

In die jare voor die revolusie het Frankryk ongewone moeilike finansiële moeilikhede ondervind. Voedseltekorte het in dié tyd 'n deurslaggewende rol gespeel. In 1789 moes die State-Generaal bymekaar geroep word weens die swak finansiële toestand van die regering. Op grond hiervan beweer Brinton dat die regering in 'n finansiële knyp was en nie die samelewing nie. Hy maak die stelling dat 'n revolusie nie in 'n ekonomiese agterlike samelewing plaasvind nie. $(\mathrm{sic})^{40}$

Eckstein bevestig dié teorie deur te sê dat die Franse samelewing vooruitstrewend eerder as agterlik was. Slegte oeste (1788-89) en ongunstige weersomstandighede in voorrevolusionêre Frankryk het ' $n$ korttermyn terugslag aan die ekonomiese lewe toegedien. ${ }^{41}$

Brinton wys daarop dat Frankryk 'n goeie voorbeeld was van ' $n$ ryk samelewing met ' $n$ verlamde regering. Statistiek van handel toon 'n opwaartse neiging deur die 18de eeu. Tog was die rykdom egter baie oneweredig versprei en die Derde Stand het nie hierin gedeel nie. ${ }^{42}$

Die koning daarenteen het homself beskou as die verteenwoordiger van God op aarde en in weelde gelewe. Lodewyk $\mathrm{XIV}$ was bekend as die Sonkoning wat die staatsinkomste gekanaliseer het na homself, sy hofhouding en sy adelike vriende. ${ }^{43}$

\section{Intellektuele faktore}

Die intellektuele oplewing wat in die Derde Stand plaasgevind het, het die reeds genoemde hoofoorsake gekonsolideer. Skrywers soos Rousseau, Voltaire en Montesquieu het die burgery attent gemaak op hul haglike omstandighede en ook die bewussyn laat posvat dat die staat sekere verantwoordelikhede teenoor sy onderdane het.

Eienaardig genoeg het intellektuele leiers nog altyd uit ' $n$ hoër klas as die opstandelinge of revolusionêre gekom. Voltaire, wat kerk en staat in sy satires gekritiseer het, was 'n groot literêre man. Saam met hom kan die werk van die 'Encyclopaediste' genoem word wat die ou regime gekritiseer het en kerk en staat belaglik gemaak het asook individuele vryheid verdedig het.

Montesquieu, ' $n$ student van die politiek, het die Engelse konstitusionele regering as die ideale en navolgenswaardig vir Frankryk voorgehou. Rousseau was een van die weinige demokratiese filosowe van sy eeu en om dié rede het sy Du Contrat Social die Bybel van die manne van die Skrikbewind geword. Hy het nie net die hoofdoktrine van die revolusie in sy werk verskaf nie, maar die volk emosioneel voorberei om te rebelleer.
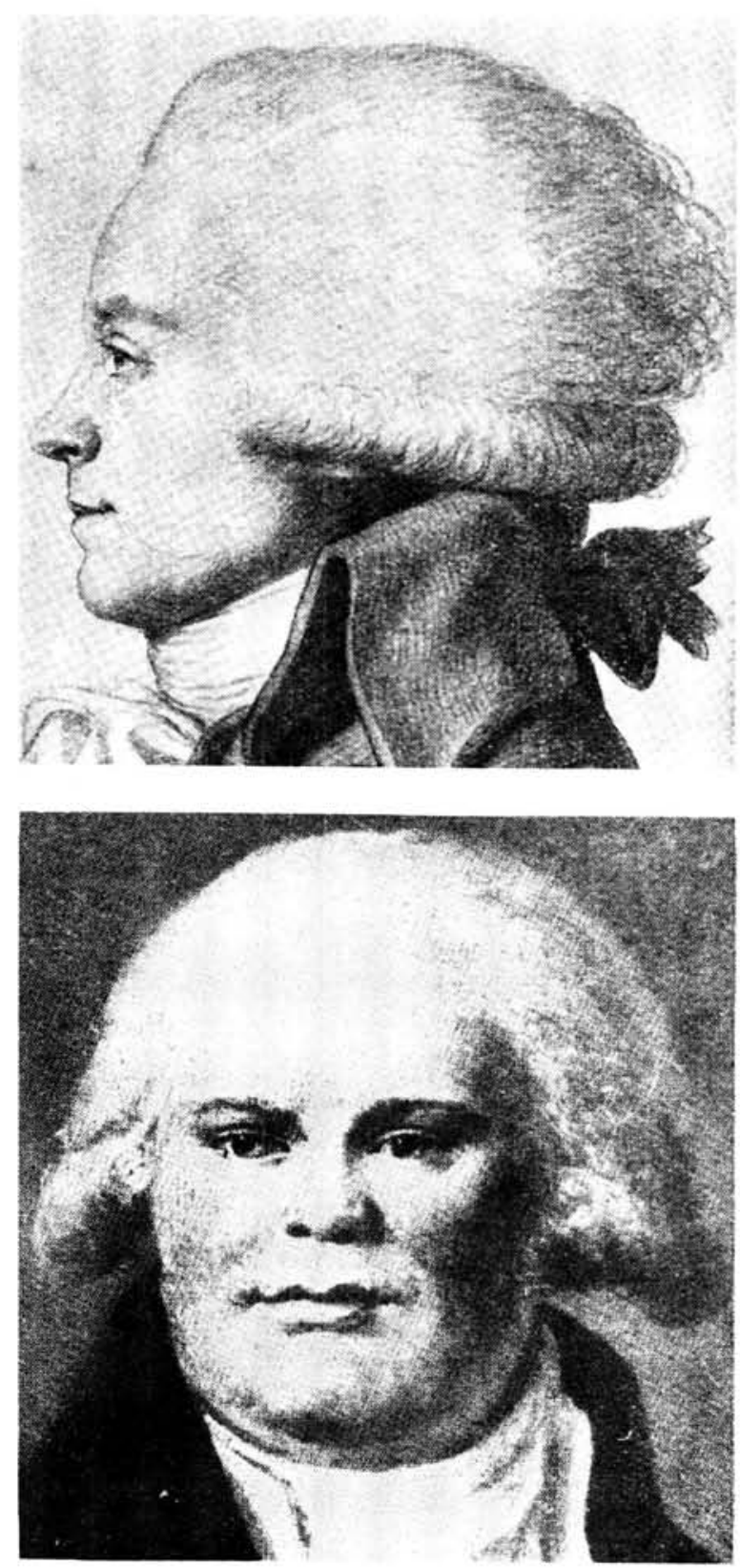

Die advokate Maximilien Robespierre en George Jacques Danton was revolusionêre leiers tydens die Franse Revolusie 
Van die revolusionêre leiers was Robespierre 'n advokaat, Mirabeau 'n briljante edellied, Marat 'n dokter en Danton 'n advokaat. Almal dus geleerders en uit ' $n$ hoër klas as die gepeupel. ${ }^{44}$

Le Bon beweer dat die volk ' $n$ revolusie sou veroorsaak omdat hulle daartoe gedwing word al verstaan hulle nie veel van die idees van hul leiers nie. Die volk interpreteer die idees van die revolusie op sy eie manier en nie op die manier van die ware outeurs van die revolusie nie. Die Franse Revolusie is ' $n$ voorbeeld hiervan. Dit het as doel die vervanging van die mag van die adel met die mag van die bourgeoisie. ${ }^{45}$

\section{Militêre faktore}

Militêre betrokkenheid aan ' $n$ revolusie as bepaler in watter mate die revolusie suksesvol is, dien gewoonlik as die spreekwoordelike vonk in die kruitvat. Volgens Chorley was die leër met die uitbreek van die Franse Revolusie al tot 'n redelike mate vervreemd van die monargie. ${ }^{46}$

Le Bon huldig dieselfde mening as Chorley in verband met die belangrike rol van die leër aan 'n revolusie en stel dit dat koningskap in Frankryk nie verdwyn het op die dag wat Lodewyk XVI onthoof is nie, maar op die presiese oomblik toe sy opstandige troepe geweier het om hom te verdedig. ${ }^{47}$

Verder het die revolusie ' $n$ verskuiwing in lojaliteit in die leër teweeggebring. Teen 1789 het die aristokrasie nog negentig persent van die offisierskorps uitgemaak, maar in Junie 1791 toe 'n nuwe eed van lojaliteit van offisiere opgestel is, is geen melding daarin van die koning gemaak nie. ${ }^{48}$

Rivarol skryf: 'It was the defection of the army effected by the ideas of the Third Estate that destroyed royalty. ${ }^{\prime 49}$

Die betekenis van die militêre faktor word deur Pettee benadruk met sy uitspraak dat 'n revolusie nie kan begin as die leër nog lojaal aan die ou regime is nie. ${ }^{50}$ In dieselfde trant verklaar Le Bon dat ' $n$ revolusie nie sonder die hulp of ten minste die neutraliteit van die leër kan plaasvind nie. ${ }^{51}$

\section{Verloop van die Revolusie}

Die soewereiniteit van die volk is in die eerste fase van die revolusie verklaar, maar dit het net op die reg om verteenwoordigers te kies, neergekom. $^{52}$

Tog het die revolusie Mirabeau se doel van 'n konstitusionele monargie bereik toe die koning, koningin en hulle kinders voor die Nasionale Vergadering verskyn het en Lodewyk XVI 'n eed van getrouheid aan die nuwe grondwet afgelê het. ${ }^{53}$

Die bestaande gesag, naamlik die van die koning, is omvergewerp en 'n nuwe revolusionêre godsdiens het tot stand gekom. Die mag wat die Jakobyne hulleself toegeëien het, was ver groter as die van die monargie wat hulle voorafgegaan het. Hulle het ' $n$ nuwe goddelikheid, naamlik die Rede geskep en die kultus het aangehou totdat Robespierre 'n persoonlike godsdiens in die plek hiervan geplaas het met homself as hoëpriester. $^{54}$

\section{Gevolge}

$\mathrm{Na}$ aloop van 'n revolusie (beweer Momboisse) is daar reaksie op die ekstremiste en hulle uitermatighede. Mense is moeg vir misdaad, korrupsie, buitensporigheid; die sterk man kom op die voorgrond en neem die leisels van die regering oor. Hy kom tot die gevolgtrekking dat min, indien enigiets bereik is. Die beloofde ideale samelewing het sekerlik nie na vore gekom nie. Die vooruitgang van die beskawing is gesluit en inderwaarheid moet weer van nuuts af begin word. ${ }^{55}$

Die gebeure in Frankryk in 1789 kan aan die hand van hierdie stelling oor die gevolge van 'n revolusie geanaliseer word. In revolusionêre Frankryk is gepoog om die hele samestelling van die samelewing te verander. Mense het moeg geword vir misbruike en korrupsie en die sterk man, Napoleon Bonaparte, het op die toneel verskyn, wat die revolusie met sy kroning as Keiser gekonsolideer en bevestig het. ${ }^{56}$

Toestande na die revolusie het grond in die hande van die boere geplaas, die en politieke mag van die adel en geestelikes gebreek, volksverteenwoordiging bewerkstellig, en die Code Napoleon daargestel wat Franse wette opgesom het. Die regte van die arbeider is verbreed en die weg vir industrie is voorberei. ${ }^{57}$

Die verbeteringe is dus nie alleen te danke aan die revolusie nie, maar ook aan Napoleon self. Die uiteindelike gevolg van die Franse Revolusie was dat Europa van die Ou Regime verander is, sodat daar teen die einde van die Napoleoni- 
tiese tydperk in 1813 skaars 'n land wes van Rusland en Turkye en noord van die Pireneë was waarvan die samelewing en politieke instellings nie grondig beïnvloed is nie..$^{58}$

\section{Russiese Revolusie}

\section{Oorsake}

Die Bolsjewistiese Revolusie in 1917 was 'n gebeurtenis wat verrassende ooreenkomste met die Franse Revolusie van 1789 gehad het. Politieke en sosio-ekonomiese toestande in Rusland op die voorraad van die revolusie het dieselfde tendense as dié in die Frankryk van 1789 openbaar.

\section{Politiek}

Die politieke gesag was outokraties en gesentreer in die hande van ' $n$ klein minderheid, onder Kerensky wat na die revolusie in Februarie by die Tsaar oorgeneem het. ${ }^{59}$ Die Tsaristiese regering het ' $n$ algemene finansiële insinking op alle gebiede van regeringsbedrywigheid beleef en, nes Frankryk, was die regering bankrot en nie die samelewing nie. ${ }^{60}$

\section{Sosio-ekonomies}

(a) Sosiaal

Die sosio-ekonomiese posisie van die Russiese landelike gemeenskap wat grotendeels op landbou aangewese was, was ewe haglik. Trotsky maak in die verband ' $n$ stelling dat indien die landbouprobleem deur die bourgeoisie opgelos sou wees, indien moontlik, die Russiese proletariaat glad nie in 1917 die mag sou kon oorneem nie. ${ }^{61}$ In sy wese was die Russiese Revolusie dus 'n boere-revolu$\mathrm{sie}^{62}$ hoewel dit deur die werkersklas gelei is. Die proletariaat is gewoonlik gelei deur die elite en Rusland was geen uitsondering nie want Karl Marx was ' $n$ professor en Lenin en Trotsky was intellektualiste. ${ }^{63}$

Die klasseverdeling wat in Frankryk bestaan het, was ook hier teenwoordig asmede die voorregte en verpligtinge wat met standverskille gepaard gegaan het. ${ }^{64}$

\section{(b) Ekonomies}

Ewe interessant is die feit dat Rusland se ekonomiese posisie op die vooraand van die revolusie vanweë 'n sinlose oorlog teen Duitsland bedenklik was. Marx het
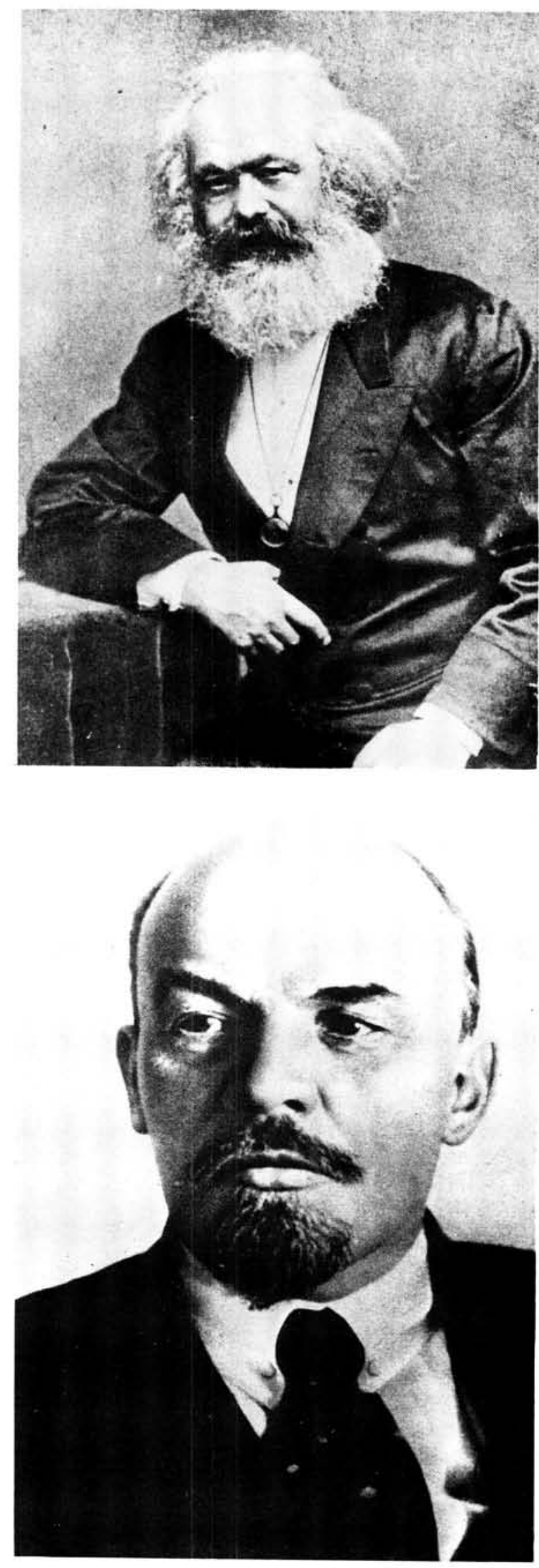

Ook in Rusland is die proletariaat deur 'n intellektuele groep gelei tydens die revolusie. Professor Karl Marx en die intellektualis Lenin is goeie voorbeelde hiervan 
beweer dat 'n voorwaarde vir wydverspreide onrus nie ' $n$ toenemende verslegting van die posisie van die proletariaat is nie, maar eerder ' $n$ verbetering in die werkers se toestand wat nie tred hou met die groeiende rykdom van die kapitaliste nie en daarom sosiale druk veroorsaak. ${ }^{65}$

Soortgelyke ekonomiese en sosiale veranderinge aan die van Frankryk het in die $19 \mathrm{de}$ eeu in Rusland plaasgevind. Die industriële groeikoers was indrukwekkend, slawe is nie net bevry nie, maar het ook begin grond besit en die middelklas was toenemend vooruitstrewend. ${ }^{66}$

Die jare tussen 1905 en 1917 het 'n opeenvolging van toenemende wanhoop en ellende gevorm. Die slegte Russiese winter van 1916-17 was nes die voorrevolusionêre Frankryk met sy swak oeste en ongunstige weersomstandighede 'n land wat 'n korttermyn ekonomiese terugslag beleef het, voorafgegaan deur ' $n$ lang tydperk van ekonomiese vooruitgang. ${ }^{67}$

Nes die Franse het die Russe ook 'n ideologie gehad beliggaam in die Kommunistiese geloof. Die Russiese Revolusie het 'n samelewing van ekonomiese gelykheid beloof. Vir Marx is die mens nie homo sapiens nie, maar homo economicus. Die mens leef net uit sy ekonomiese belange. ${ }^{68}$

Die nypende voedseltekort in 1917 was die vonk wat die revolusionêre kruitvat help ontplof het. Beals beskryf die treurige voorrevolusionêre toestande in Rusland as 'a pre-epileptic nightmare' en omtrent die voedselskaarste sê hy 'millions upon millions of people were nearly breadless and fifteen million soldiers along a thousand miles of icy front were rarely supplied.' Hele afdelings soldate moes sonder kos of skoene veg. ${ }^{69}$

\section{Intelektueel of Ideologies}

Ook het die nuwe ideologiese denkrigting wat in 'n groot mate met dié van Rousseau en Voltaire ooreengekom het, momentum aan die revolusie van 1917 verleen. Die beginsels wat deur die Oktober-revolusie neergelê is, was die van ' $n$ wêreld sosialistiese stelsel, die internasionale kommunistiese en werkersklasbewegings en die van die nasionale be- vrydingsbeweging ${ }^{70}$ Dit het vergelyk met die ideale van vryheid, gelykheid en broederskap waarop die Franse Revolusie gebaseer is. Die denkers en die filosowe was ook soos die Franse lede van die bourgeoisie en nie van die proletariaat of werkersklas nie. Karl Marx was 'n professor en Lenin en Trotsky intellektualiste. ${ }^{71}$

\section{Militêr}

In Maart 1917 is die Russiese soldaat voor die keuse gestel om tussen die Tsaristiese regime en die bourgeoisie revolusie te kies. Die Petrograd soldate het gemuit pleks om die opstandige magte aan te val. Die Tsaar het nes die Franse koning geval omdat sy soldate hom in die steek gelaat het en die leër het die nuwe Voorlopige regering van Kerensky aangehang. $^{72}$

\section{Verloop}

Wat die revolusie self betref, is die nuwe gesag wat tot stand gekom het ook gekenmerk deur aanvanklike onstabiliteit. Die kommuniste moes, nes die Jakobynse klub van die Franse Republiek, gedurende die eerste dae van hul onbestendige bewind alles in die stryd werp om 'n teenrevolusie die hoof te bied. Waar die Franse Republiek van 1789 deur die Europese moondhede as ' $n$ bedreiging beskou is, is Rusland weer in ' $n$ bloedige burgeroorlog tussen kommuniste en rojaliste gedompel. Rusland is ook bedreig deur westerse moondhede.

In Rusland sowel as Frankryk het die boere die meerderheid van die bevolking gevorm en is die landboukundige probleme tot voordeel van die revolusionêre gebruik. Indien die boere nie die onderskeie bourgeoisie of sosialistiese bewegings ondersteun het nie, sou dit nie geslaag het nie. $^{73}$

\section{Gevolge}

Wanneer gelet word op die gevolge van die Bolsjewistiese Revolusie is verskille sowel as ooreenkomste met die Franse Revolusie ooglopend. 'n Nuwe regerende en besittersklas het in Frankryk tot stand gekom. In Rusland was daar ' $n$ oordrag van ekonomiese mag van een groep na ' $n$ ander eerder as ' $n$ gelyke verdeling van ekonomiese mag of gelyke verdeling van verbruikersgoedere. 'n Nuwe Russiese burokrasie was die bevoorregte klas wat eiendom besit het. ${ }^{74}$ 
Die permanente en langdurige gevolge van die Franse Revolusie het onder andere regsgelykheid, vryheid en onafhanklikheid vir die handel en nywerheid meegebring. Dit het ook daartoe gelei dat grond regmatig onder kleinboere verdeel is. Hierteenoor was die demokrasie wat in die Sowjet-Unie tot stand gekom het allesbehalwe 'n demokrasie ofskoon die grondwet dit ${ }^{75}$ aan sy republieke verseker het.

Die handel en nywerheid is onder staatsbeheer gebring en tot op 'n groot hoogte genasionaliseer en hoewel die Russiese aristokrasie selfs in 'n groter mate as die Franse adel van hul eiendomme onteien is, het die Russiese burgery wat oorwegend plattelands georiënteerd was, nie regstreeks hieruit voordeel getrek nie.

\section{Iraanse Revolusie (1979 - )}

Die onlangse revolusie in Iran (1979) is deur verskeie skrywers as 'n raaiselagtige gebeurtenis beskrywe: ten tye van die revolusie was Iran 'n opkomende staat met ' $n$ indrukwekkende militêre statuur. Volgens Richard Burt het Iran binne 'n dekade 'n eersterangse 'middelvlak' militêre mag geword. In die lig van militêre ontwikkelings was dit 'n ope vraag of Iran se militêre ambisies nie sy tegniese vaardigheid oorskry het nie. ${ }^{76}$

Nes die Sjah in die voor-oorlogse periode nadruk gelê het op die skepping van 'n ekonomiese mag, het hy later klem gelê op ekonomiese ontwikkeling en streekssamewerking. Weens sy olieproduksie kon Iran spesiale verhoudinge met supermagte aanknoop, veral in die geval van die Verenigde State. ${ }^{77}$

Op die oog af het die Iraanse bevolking nie veel gehad om oor te kla nie en op die vooraand van die revolusie het die Sjah oënskynlik die steun van die land se veiligheidsmagte geniet. Ten spyte van sy militêre opbou, het Iran selfs onder die Sjah ernstige probleme met sy militêre slaankrag gehad ${ }^{78}$ en het die vors se aanhang nie veel verder as die hoogste militêre hiërargie gestrek nie.

Uiteenlopende groepe het uit protes geledere gesluit teen oorhaastige verwestering, die ondergrawing van tradisionele waardes en lewenstyle en 'n outokratiese bedeling. Die Sjah was feitlik ' $n$ monarg in dieselfde sin as Lodewyk XVI en Tsaar Nicolaas $11 .^{79}$

Terselfdertyd het die bevolking in ' $n$ nasionale identiteitskrisis verkeer, iets wat die Sjah skrome- lik oor die hoof gesien het. Belangrik is dit om daarop te let dat die Sjah nes genoemde heersers kontak met sy onderdane verloor het.

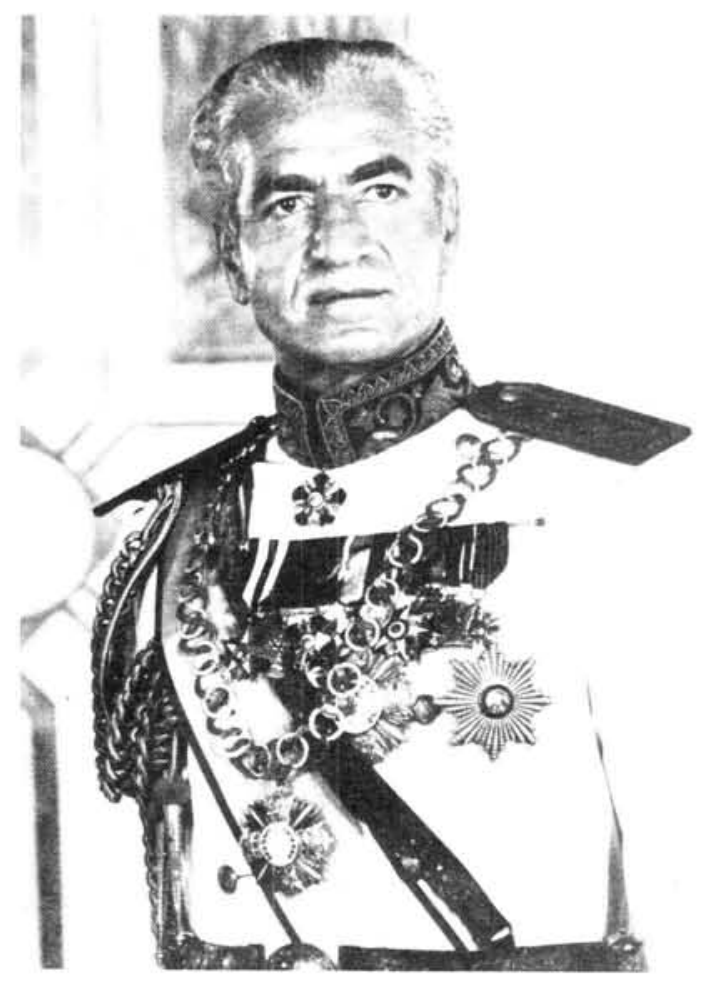

Die Sjah van Iran het nie besef dat die bevolking in 'n identiteitskrisis gewikkel was nie

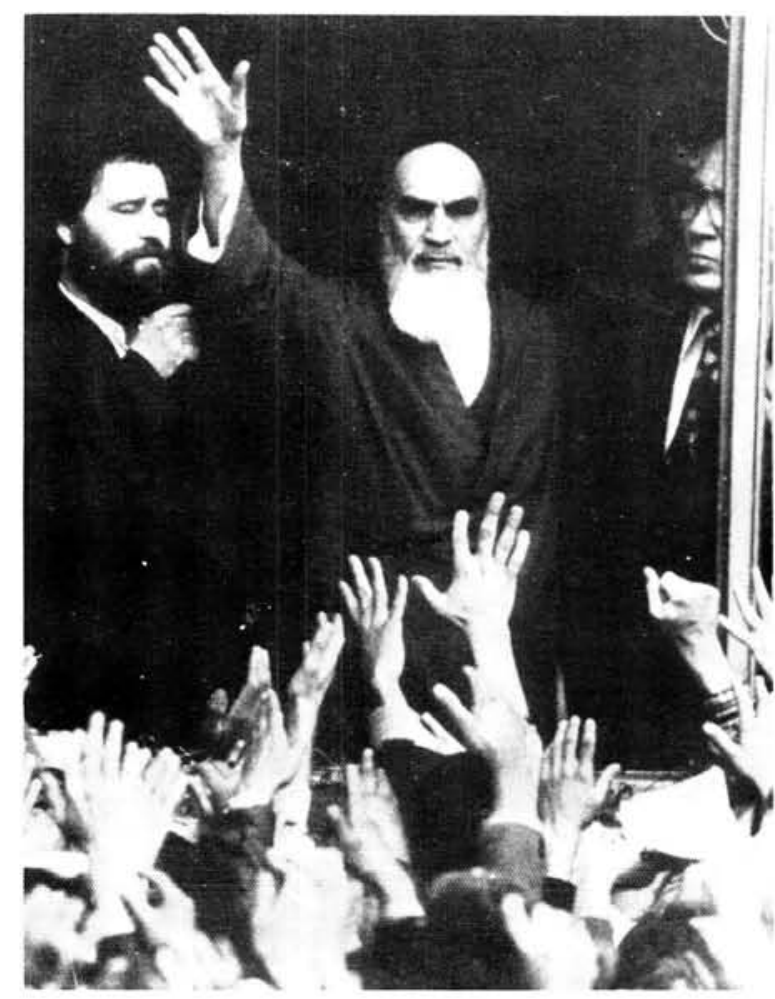

Die revolusionêre geestelike leier Ayatolla Khomeini onder wie se bewind openbare teregstellings feitlik 'n alledaagse verskynsel geword het in Iran 
Na die val van die Sjah is Iran (nes met Frankryk en Rusland die geval was) in 'n tydperk van sosiale onrus, openbare geweld, politieke onstabiliteit, wetlike wanorde en ekonomiese verval gedompel. Die openbare teregstellings deur die Islamitiese Wagte wat feitlik ' $n$ alledaagse verskynsel geword het, herinner sterk aan die terreurbewind van die Jakobynse klubs. ${ }^{80}$ Die interne magstryd tussen die verskillende groeperinge in die nuwe bewind, naamlik die revolusionêre geestelikes, die militante Marxiste en die gemagtigde intellektueles, is ewe opvallend. ${ }^{81}$

Leno Rust beweer dat die revolusie in Iran wel die noodsaak van streeksamewerking onderstreep het, maar dat dit helaas weinig duidelikheid gebring het ten opsigte van interne bedreigings. Hy kom tot die gevolgtrekking dat die Iraanse rewolusie ' $n$ nasionale opstand met ' $n$ sterk anti-Westerse karakter geblyk het te wees. $^{82}$

\section{Sjinese Revolusie}

Alvorens daar van die Ooste as revolusionêre gebied afgestap word, kan die Sjinese Revolusie vlugtig in oënskou geneem word. Dié revolusie word ook met die Russiese Revolusie van 1917 vergelyk en ooreenkomste sowel as verskille word uitgelig.

Die Sjinese Burgeroorlog (1926-49) wat deur die Sjinese Kommunistiese Party gelei is, het 22 jaar lank geduur. Die landboukrisis in Sjina in die twintiger- en dertigerjare en die geleidelike verarming van die plattelandse massas bied ' $n$ goeie begrip van die Sjinese Revolusie. Die geleidelike kommersialisering van die landbou het boere swaar getref terwyl die stedelike middelklas in grond belê het.

Die revolusie was ' $n$ ware militêre revolusie gegrond op sosio-ekonomiese oorwegings. Ellis beweer dat die weermag ' $n$ ware volksweermag was wat ter beskerming van hul eie ekonomiese belange geveg het. ${ }^{84}$

Ooreenkomste tussen die Sjinese Revolusie en die Russiese Revolusie was dat beide deur die werkersklas gelei is met ' $n$ Marxisties-Leninistiese party as kern. Tweedens is albei op 'n werker-boer ooreenkoms gebasseer. Derdens is die staat se mag deur 'n gewelddadige revolusie en diktatuur van die proletariaat bevestig. In albei gevalle is die sosialistiese stelsel na die oorwinning van die revolusie opgebou. ${ }^{85}$ 'n Uitstaande verskil tussen die twee revolusies was dat die Russiese Revolusie met gewapende opstande in die stede begin het (dit was ook die geval met die Franse Revolusie) en toe na die platteland versprei het. Hierteenoor het die Sjinese Revolusie landwyd versprei deur die omsingeling van plattelandse gebiede en finale oorname van die stede. ${ }^{86}$

Mao Tse-tung se stelling: 'political power grows out of the barrel of a gun' was die grondslag waarop hy sy revolusie gevoer het en waarvolgens dit in ander lande ook toegepas word. ${ }^{87}$

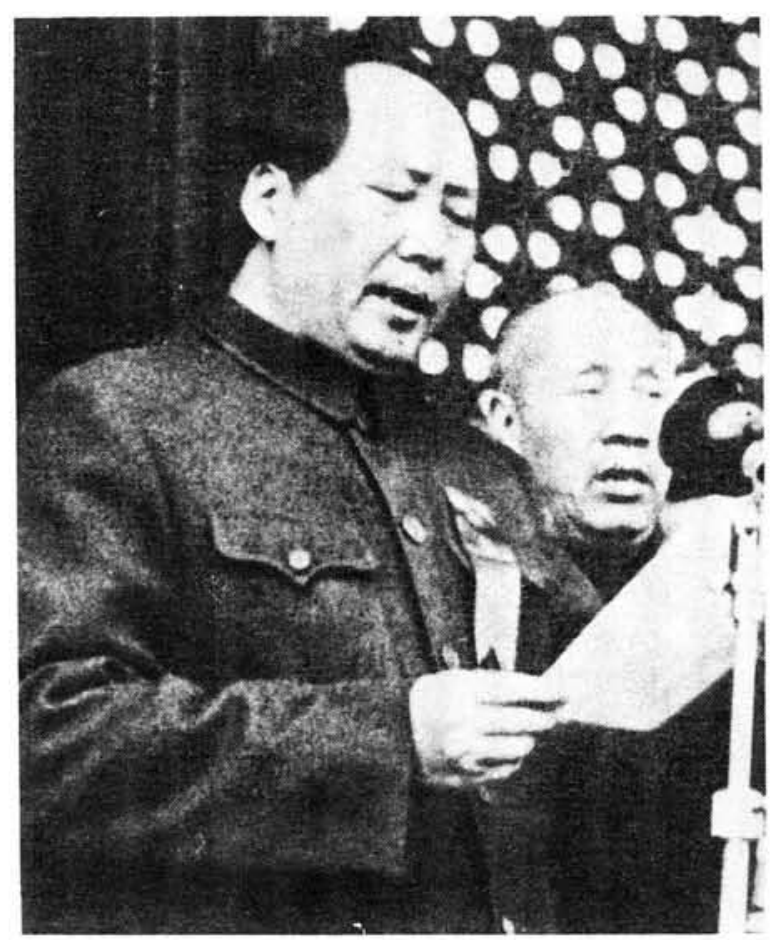

Mao Tse-tung het gesê: 'Political power grows out of the barrel of a gun'

\section{Meksikaanse Revolusie}

Die Latyns-Amerikaanse kontinent as revolusionêre kruitvat is die volgende onder bespreking. Die Meksikaanse en die Kubaanse revolusies word hier bespreek aangesien hulle in aard en motivering teenoor mekaar staan.

Die Meksikaanse Revolusie wat in 1910 begin het en eers in 1940 afgehandel is, was inderwaarheid 'n sosiale en ekonomiese evolusie. Meksiko is ' $n$ land van gemengde Spaanse en Indiaanse kulture. Die Meksikaanse voor-revolusionêre ekonomie was hoofsaaklik landelik en landboukundig. ${ }^{88}$ Tagtig tot negentig persent van die landelike bevolking was sonder eiendom en in die stede en dorpe het agterbuurttoestande geheers. ${ }^{89}$ 
Hoewel Meksiko die meeste van alle LatynsAmerikaanse lande aan geweld blootgestel was en die revolusie ook die vernietigendste was wat in dié lande plaasgevind het, is dit opmerklik dat 'n skrikbewind wat so prominent by die Russies-, Franse- en Iranese revolusies aanwesig was, hier totaal ontbreek het. Die Meksikaanse Revolusie verskil van die reeds genoemde revolusies aangesien daar nooit ' $n$ ideologie verkondig is nie. Dit was 'n revolusie wat uit Meksiko gebore is en deur Meksikane gevoer is. Verder was daar nie 'n militêre fase teenwoordig (soos dié van Napoleon) nie. Vandag kan politieke leiers min veranderings maak omdat die revolusie instellings vasgepen het. ${ }^{90}$ Die ander revolusie in Suid-Amerika wat die res van die Latyns-Amerikaanse wêreld asook die Derde Wêreld beïnvloed het, was dié in Kuba.

\section{Kubaanse Revolusie}

Ontevredenheid met die ou regime, vervreemding van die intellektueles, ekonomiese probleme en spanninge by belangrike groepe van die bevolking was almal oorsaaklike faktore wat op die vierjarige Kubaanse Revolusie van 1956-1959 uitgeloop het. In 1959 het Fidel Castro, die revolusionêre middelklasleier, wat politikus en advokaat was, die bewind by genl Batista oorgeneem. ${ }^{91}$

Soos die Franse en Russiese Revolusies het die Kubaanse Revolusie gepoog om sy boodskap van redding na sy verblinde bure deur te dra. Verder het die Kubaanse Revolusie ' $n$ verskeidenheid spreuke en ideologiese stellings opgelewer. ${ }^{92}$

Ché Guevara het beweer dat die Kubaanse Revolusie in Latyns-Amerika bewys het dat die populêre magte ' $n$ oorlog teen die leër kan wen (soortgelyk soos in Sjina); dat dit nie altyd nodig is om te wag tot die voorwaardes van ' $n$ revolusie teenwoordig is nie aangesien die opstandigheidssentrum dit kan skep; in onderontwikkelde Amerika was die gebied van die gewapende stryd hoofsaaklik in die platteland ('n vergelyk kan weer hier met Sjina getref word). ${ }^{93}$

Volgens Debray leer Fidelisme in Latyns-Amerika dat nasionalisme geïmpliseer word deur die omverwerping van 'n semi-koloniale staat, die vernietiging van die leër en die instelling van sosialisme. In die laaste plek moet die SuidAmerikaanse klasse en nasionale stryd saamgaan. Hy beweer dat dit onmoontlik is om die
Amerikaanse oorloë van nasionale bevryding onder dieselfde afdeling as dié van Asië en Afrika te klassifiseer. ${ }^{94}$

In 'n onlangse artikel beweer Conell-Smith dat Kuba 'n prominente rol gespeel het onder lande van die Derde Wêreld en veral in die sogenaamde stryd teen kolonialisme. Laasgenoemde aspek is deur 'n Kubaanse betrokkenheid in Afrika belig, hoewel Castro se beleid in Angola en ander dele van die kontinent aansienlike Sowjet steun geniet het. ${ }^{95}$

Die revolusies wat Castro en Guevara verkondig is dus ideologies, militêr en polities gefundeer gepaardgaande met geweld en die instelling van sosialisme.

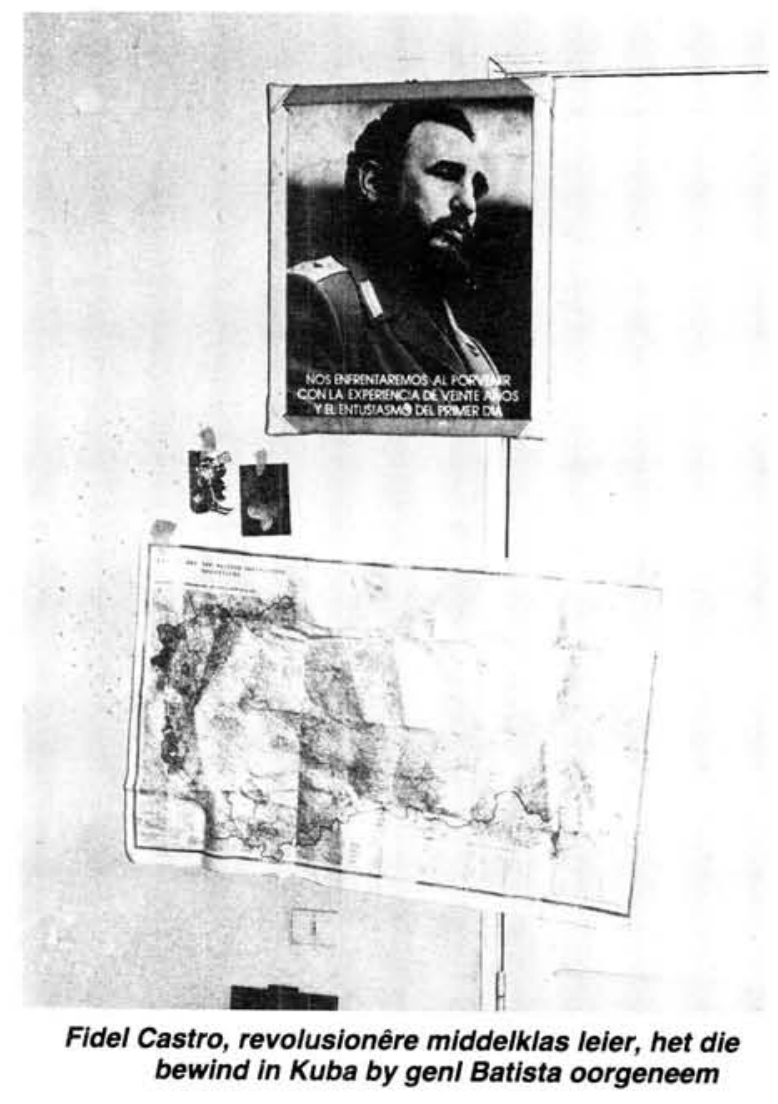

\section{Die Revolusie in Afrika}

In Nature of Revolution beweer Beals dat die Mau Mau se onafhanklikheidstryd in Kenia deel van 'n Kontinentale stryd was wat meer as ' $n$ twintigtal nuwe onafhanklike regerings tot stand gebring het. ${ }^{94}$

Die Argentynse revolusionêre leier Ché Guevara het na sy suksesse om revolusie in Latyns-Amerika te bewerkstellig, ook besluit om sy tegniek uit te voer na die onderontwikkelde wêreld. In 
1959 het hy Afrika vir die heel eerste keer besoek. $^{95}$

Die drie guerilla-leiers met wie Guevara gepraat het, was Mondlane van Mosambiek, Cabral van Guinea Bisseau en Neto van Angola. Guevara het advies en aktiewe hulp van Kubaanse politieke en militêre spesialiste aangebied wat in dieselfde land gestasioneer is. Van 1968 het Kuba voortgegaan met sy taak en spesifiek gekonsentreer op Guinea, Kongo (Brazzaville), Tanzanië, Algerië en Libië. ${ }^{96}$

Pacific Defence Reporter beweer dat die idees van revolusionêre leiers asook die weerstand teen kolonialisme nie die belangrikste gevare in Afrika is nie, maar wel 'n voedselskaarste en hongersnood. 'Forget Marxism. Hunger will be the great destabilising factor in Africa throughout the 80's and beyond, unless some new 'loaves and fishes' miracle is achieved in the meantime ${ }^{97}$ Hongersnood is ' $n$ wydverspreide verskynsel in Afrika en kan die belangrikste oorsaak vir revolusie wees. In 50\% van die state in Afrika is hongergeteisterde gebiede. In 1965 het Afrika in $90 \%$ van sy voedselbehoeftes kon voorsien, en in $1980,80 \%$. Volgens projeksies sal die syfer in die jaar 2000 tot $60 \%$ gedaal het.

\section{Revolusie in die toekoms}

' $n$ Vooruitskouing van ' $n$ toekomstige revolusie is al deur verskeie geleerdes wat die revolusie as kontemporêre verskynsel bespreek het, gemaak. Eugene Kamenka is van mening dat die revolusie van die toekoms in 'n gevorderde demokratiese, geïndustrialiseerde samelewing slegs teenrevolusie kan wees, die inpalming van mag deur ' $n$ groep wat die herinstelling van despotiese gesag beoog. Hy voorsien dat die intensifisering van die militêre stryd of van bevolkingsdruk op voedselbronne so 'n moontlikheid werkliker kan maak as wat dit op die oog af lyk. Kamenka wys daarop dat toekomstige revolusies in die Kommunistiese wêreld nie onmoontlik lyk nie. ${ }^{98}$

Momboisse vrees nes Kamenka dat demokrasie vernietig sal word en dat op die ruïnes daarvan 'n diktatuur sal ontstaan wat alle opstand sal onderdruk en alle vryheid sal uitwis. ${ }^{99}$

Die impuls vir die magsoorname in industriële samelewings word deur die jeug, wat tot ' $n$ mindere mate as hul ouers in die huidige bestel geïntegreer is, verskaf. In dié verband speel stu- dente ' $n$ groot rol as voorlopers van ' $n$ revolusie. $^{100}$

Vir die doel van die studie is etlike klassieke modelle geselekteer omdat hierdie revolusies hoogtepunte was in die evolusie van revolusionêre konflik. Nog 'n rede waarom mense opnuut moet kyk na revolusie as fenomeen is omdat die wêreld weer in die teken van totale revolusie staan soos dit behandel word deur Toffler in Future Shock wat in 1972 die lig gesien het. Toffler beweer dat die mens van die sewentigerjare tegelykertyd ' $n$ jeugrevolusie, 'n seksuele revolusie, 'n rasserevolusie, 'n koloniale revolusie, 'n ekonomiese revolusie en die vinnigste en mees diepgaande tegnologiese revolusie in die geskiedenis ervaar. ${ }^{101}$

Die mensdom beleef ' $n$ algemene krisis van industrialisme en is met ander woorde midde in die superindustriële revolusie. Die aanpassingskrisis in 'n nuwe wêreld of toekomsskok is Toffler se tema van sy boek. ${ }^{102}$

Vir die volgende 30 tot 40 jaar voorsien hy 'not a single wave of change but a series of terrible heaves and shudders'. Sekere radikale veranderinge is volgens Toffler veels te laat. ${ }^{103}$

As oplossing vir die probleem dat menslike skade deur verandering berokken word, stel hy voor dat die mens se aanpassingsmoontlikhede uitgebrei moet word, naamlik die sentrale opvoedingstaak gedurende die superindustriële revolusie. ${ }^{104}$

In sy tweede werk Third Wave neem Toffler die probleme van aanpassing in aanmerking, maar benadruk die probleme indien die verandering nie vinnig genoeg sou geskied nie. Hy konsentreer op die rigting waarheen die verandering ons neem. Sy drie fases of golwe bestaan uit ' $n$ landboukundige fase, ' $n$ industriële fase en die derde fase wat so pas begin het. Hoewel die huidige tydsvak baie benamings het, noem hy dit die superindustriële revolusie. ${ }^{105}$

Die belangrikste politieke ontwikkeling van ons tyd is die verskyning in ons midde van twee basiese kampe waarvan een aan die Tweede Golf beskawing, die ander aan die Derde verbind is. Die bewaring van die kerninstellings van die industriële samelewing is die kern (familie), die massa-opvoedingsisteem, die reuse korporasie, die massa-vakbond, die gesentraliseerde nasiestaat en die politiek van die pseudo-verteenwoordigende regering. Die Derde Golf 
erken vandag se ernstige probleme van energieoorlog, voedselskaarste en armoede tot ekologiese degradasie, afbreking van die gesinsverhoudinge en verbreking van die stedelike gemeenskap wat nie langer binne die industriële beskawing opgelos kan word nie. ${ }^{106}$

Dis treffend dat die probleme van die toekoms nie meer in politieke gesag en omverwerping van regeringsgesag lê nie, maar die skepping van 'n nuwe sosiale orde. Nasionale belange maak plek vir gemeenskaplike belange..$^{1{ }^{7}}$

Môre se ontwikkelingstrategie sal nie van Washington of Moskou, Parys of Genéve kom nie, maar van Afrika, Asië en Latyns Amerika. Hulle sal nie die ekonomie oorbenadruk ten koste van die ekologie, kultuur, godsdiens of familie struktuur en die sielkundige dimensies van bestaan nie. ${ }^{108}$

\section{Evaluering}

Die revolusies wat hier bespreek is, toon in 'n meerdere of mindere mate opvallende parallelle. By die bespreking van die revolusies in Rusland en Iran is sommige van hierdie tendense kortliks met die Franse Revolusie gekontroleer. Tog waarsku talle akademici dat daar geen werklike gronde bestaan om te glo dat enigiemand oor voldoende kennis en insig beskik om formules daar te stel vir die voorspelling van revolusies nie. ${ }^{109}$

Revolusies het heelwat gemeenskaplike faktore:

(a) Eerstens is dit opmerklik dat ekonomiese faktore ' $n$ belangrike rol in al die revolusies gespeel het. Selfs in Iran, wat 'n welvarende olie uitvoerland was, was ontevredenheid oor die wyse waarop geld vir openbare belang bestee is. ${ }^{110}$ In Meksiko bv is die revolusie suiwer op swak sosio-ekonomiese faktore gevoer.

(b) Tweedens vind ons in die pre-revolusionêre gemeenskap ' $n$ definitiewe en inderdaad bittere klasse-haat. Die Latyns-Amerikaanse filosofie was dat klassehaat en nasionalisme noodwendig saamgaan in die voer van ' $n$ revolusie. Wat die gewone burgery betref, is hierdie antagonisme meer intens, veral in die geledere van die meer gegoedes wat in die hedendaagse terminologie as die middelklas bestempel word. Dié groep is dan ook die leiers van die evolusie, bv Robespierre die advokaat, Trotsky die professor, Guevara die medikus en Castro die politikus.

(c) Derdens is daar wat bestempel kan word as die oordrag van getrouheid en aanhanklikheid aan die kant van die intellektuele groep - die denkers. Feitlik sonder uitsondering is hierdie beleidsvormers altvd teenwoordig en as sodanig besonder aktief in die pre-revolusionêre gemeenskap. ${ }^{112}$ Hier dink ons aan Voltaire en Rousseau in Frankryk, Marx en Engels in Rusland, Mao Tse-tung in Sjina, Castro en Guevara in Latyns-Amerika en tot 'n minder mate in Afrika.

(d) In die vierde plek is die staatsmasjinerie van 'n pre-revolusionêre regering in die reël ondoeltreffend, deels vanweë nalatigheid, maar ook as gevolg van stagnering tov organisasie en werksmetodes. ${ }^{113}$ Die 'ancien regime' in Frankryk was totaal ondoeltreffend tov die invordering van belasting, die indeling van die land in talryke provinsies wat elk 'n outonome bestuur het, asook 'n staatsadministrasie wat verward was. In Rusland het die Tsaar wel die opeenvolgende Dumas ingestel wat sogenaamd inspraak in landsbestuur sou hê, maar hulle is telkens ontbind wanneer hy daarmee verskil het.

(e) Verder gebeur dit ook dat lede van die heerserklas (of die ou aristokrasie) vertroue verloor in hulself en die tradisies en lewenstyl van hul stand. Gevolglik skaar hulle hul by die revolusionêre groep. ${ }^{114}$ Dit was die geval in Frankryk, Rusland, Latyns-Amerika en Sjina.

(f) Verder is dit interessant dat politieke revolusies in die begin fase gekenmerk word deur besliste optrede aan die kant van die owerheid in ' $n$ verbete poging om die revolusie in die kiem te smoor. Dikwels gebeur dit dat die beheer van 'n pre-revolusionêre regering oor sy veiligheidsmagte swak is, bv in die geval van Iran, Frankryk van 1789 en Rusland van 1917.

(g) Laastens vind mens die verskynsel dat 'n revolusionêre staat (soos Frankryk ná 1794), die revolusionêre gedagte na ander lande wil uitdra. Frankryk onder veral Bonaparte wou die pouslike state (vgl Lombardye) onder die dekmantel van bevryding (van Oostenryk) bevry. Al wat gebeur het, is dat 'n vorm van revolusionêre imperialisme onder Napoleon tot stand gekom het. Dit was ook die geval met Rusland: tot vandag toe poog die Sowjet-Unie om revolusie na die vrye wêreld uit te voer, soos bv in Mosambiek, Angola en Zimbabwe. Dieselfde geld vir 
en Kuba. (Waaronder die Suid-Amerikaanse state ook inbegryp word). Op 'n soortgelyke wyse poog Iran om sy geestelike ideologie uit te dra (vgl Irak).

\section{Samevattend}

By wyse van hipotese kan die voorvereistes vir revolusie in kategorieë verdeel word:

(a) Provokasie. Momboisse beweer in sy Blueprint of Revolution dat ' $n$ potensiële revolusionêre situasie bestaan in 'n land waarin die groot meerderheid burgers nie oor ' $n$ minimale redelike lewenstandaard beskik nie. Hy gaan verder deur te beweer dat revolusies voorafgegaan word deur algemene katastrofes soos hongersnood en oorloë. Sodanige gebeure verswak die lojaliteit van die massa. ${ }^{115}$ In die Franse, Russiese en Iraanse Revolusie het provokasie gedien as een van die direkte aanleidende oorsake.

(b) 'n Verenigde openbare mening is volgens Gottschalk 'n tweede voorvereiste. Solank as wat revolusionêre groepe onderling verdeel is, is dit onwaarskynlik dat hulle in hul gemeenskaplike doel sal slaag. Terselfdertyd moet die breër volksmassa hulself kan identifiseer met die oogmerke van die revolusionêre groepe. ${ }^{116}$

(c) Hoop. Hiermee word bedoel die toekomsverwagtinge en aspirasies van die onderdrukte groep. Hierdie hoop is gebaseer op die bestaan van een of meer hervormingsprogramme wat aan die na-revolusionêre samelewing voorgehou word, soos in die Franse, Russiese en Kubaanse Revolusies die geval was. ${ }^{117}$

(d) Die teenwoordigheid van 'n sterk leierelement in die revolusionêre groep. ${ }^{118}$

(e) Laastens noem Gottschalk 'n lae moreel in die geledere van die pre-revolusionêre magte as ' $n$ definitiewe oorsaak. Hy beskou dit ook as die onmiddellike oorsaak van revolusie. Lodewyk XVI kon nie op die verenigde weermag, geestelikes of adel reken nie en het homself aan die revolusionêre gees onderwerp. ${ }^{119}$ In Iran kon die Sjah ook nie op die veiligheidsmagte reken nie, hoewel dit op die oog af gelyk het of hy sterk staan, en hy moes abdikeer.

\section{Slot: Riglyne vir voorkoming}

In die beskikbare ruimte is slegs enkele verteenwoordigende grepe wat die revolusionêre proses kenmerk, toegelig. Die doel was hoofsaaklik om die leser ' $n$ algemene indruk van revolusie te bied soos dit waarskynlik in 'n samelewing sal verloop indien gunstige faktore daarvoor bestaan.

Een kardinale vraag wat egter onbeantwoord bly, sentreer om die kwessie van voorkomende stappe om die revolusionêre proses te voorkom of te onderbreek. In hierdie verband word dié aspek ook in globale terme behandel eerder as om op die detail van maatreëls en prosedures (soos bv teeninsurgensie-operasies) in te gaan. Voorts wil die outeur ook daarop wys dat die projeksie wat vervolgens gebied word, nie op 'n spesifieke staat van toepassing is nie, maar eerder gegrond is op ' $n$ algemene model wat die breë spektrum van wêreldstate verteenwoordig. Die aanname wat gemaak word, is dat noodwendige veranderinge deur evolusionêre ontwikkeling eerder as revolusie by wyse van strukturele geweld moet plaasvind. Die projeksie word onder vier hoofde gedoen, te wete polities-staatkundig, ekonomie, nasionale veiligheid en maatskaplik.

\section{Polities-staatkundig}

Ofskoon politieke gesag van land tot land verskil, kan nouliks getwyfel word oor die feit dat enige vorm van eng gesentreerde politieke gesag (in die hande van enkelinge en magsgroepe) ' $n$ revolusionêre proses kan ontketen. Dit is dus belangrik dat ' $n$ staat nie in so bedeling sal stagneer nie, maar op ' $n$ deurdagte en ordelike wyse veranderinge sal ondergaan met ' $n$ klemverskuiwing in die rigting van gedesentraliseerde politieke gesag op verskillende vlakke (nasionaal en plaaslik). Twee belangrike oorwegings wat hier geld, is eerstens die noodsaaklikheid van onderhandelinge/samesprekings wat tot ' $n$ algemene konsensus sal lei, en tweedens die feit dat alle belangegroepe in die polities-staatkundige ontwikkeling van ' $n$ land of gebied moet deel.

Soos dit in die voorafgaande bespreking duidelik aan die lig gekom het, kan die rol van die staatsdiens nie onderskat word nie. Dit kan kortliks gestel word dat ' $n$ ondoeltreffende en korrupte staatsdiens gewoonlik simptomaties is van 'n staat wat in die rigting van revolusie beweeg; in hierdie opsig is dit dus ook van uiterste belang dat die staatsmasjinerie voortdurend in die teken van rasionalisering moet staan om aan die veranderende behoeftes van die samelewing te voldoen. 


\section{Ekonomie}

Die Iraanse Revolusie het getoon dat ekonomiese welvaart as sodanig nie die moontlikheid van 'n revolusie sal besweer of teëwerk nie. In hierdie verband moet kennis geneem word van die noodsaak aan een of ander vorm van oorhoofse en gekoördineerde ekonomiese beplanning waardeur regionale ontwikkeling gestimuleer en nuwe bedryfsektore geskep word.

In 'n enger sin moet veral aandag gegee word aan aspekte soos die skep van werksgeleenthede en beroepsopleiding. Terselfdertyd moet die nasionale ekonomiese welvaart ook in die persoonlike welvaart van die individu weerspieël word.

Soos Toffler trouens aangedui het, sal ekonomiese faktore en veral industriële ontwikkeling ' $n$ uiters belangrike rol in toekomstige revolusies speel. Wat egter nie uit die oog verloor mag word nie, is dat gesonde nywerheidsontwikkeling gebaseer moet wees op ' $n$ kerngesonde landboubedryf - 'n voorvereiste waaraan talle wêreldlande (ook in Afrika) kwalik voldoen. Een aspek wat hier uitgesonder moet word, is die beskikbaarheid van voldoende voedselbrorine: - $\mathrm{Na}$ poleon Bonaparte het aangevoer dat ' $n$ leër op sy maag marsjeer, maar na analogie hiervan kan ook die stelling gemaak word dat die leërs van revolusie nog beter op 'n leë maag marsjeer!

\section{Nasionale veiligheid}

Die feit dat ' $n$ revolusie in die teenwoordigheid van lojale veiligheidsmagte slegs kan slaag indien 'n sterk buitelandse moondheid die revolusionêre groep steun, kan nie genoeg beklemtoon word nie. Daarteenoor sal 'n dislojale veiligheidskomponent die kanse dat ' $n$ revolusie sal slaag, verhoog.

Die regering van ' $n$ staat sal moet toesien dat die veiligheidsmagte in alle opsigte doeltreffend kan optree. Oorwegings wat hier ter sprake kom, is onder meer 'n effektiewe dienspligstelsel, opleiding, aantreklike diensvoorwaardes, esprit de corps, dissipline en 'n hoë moreel.

In moderne revolusionêre oorlogvoering beklee sielkundige optrede 'n sleutelposisie. Daarom moet elke lid van die veiligheidsmagte - net soos die terroris en die guerillavegter - uiters gemotiveerd kan optree. Derhalwe moet die staat ook toesien dat die sielkundige aspekte van die soldaat se opleiding nie verwaarloos word nie.
Een aspek wat nie uit die oog verloor moet word $\mathrm{nie}$, is $\mathrm{nl}$ dat die lojaliteit van die veiligheidsmagte tot op groot hoogte deur die openbare mening beïnvloed word. Dit is belangrik dat die veiligheidsmagte ook die ondersteuning en lojaliteit van die bevolking sal geniet. Derhalwe moet daarteen gewaak word dat die veiligheidsmagte in 'n negatiewe lig gestel word (bv deur afbrekende kommentaar en beriggewing in die openbare media) en besliste stappe moet gedoen word om die subtiele ondermyning van die staat se militêre paraatheid die hoof te bied. In hierdie verband kan gemeld word dat kommunistiese groepe dmv frontorganisasies voortdurend poog om ' $n$ lae moreel in die geledere van ' $n$ land se veiligheidsmagte te bewerkstellig ( $\mathrm{vgl}$ bv die pasifistiese bewegings in die VSA en Wes-Europa).

\section{Maatskaplik}

Maatskaplike faktore wat ' $n$ rol in klassieke revolusies gespeel het, was grotendeels ekonomies van aard. Revolusies in die moderne tydvak het egter getoon dat maatskaplike verdelings volgens ander maatstawwe en faktore situasies kan skep waaruit revolusies mettertyd kan ontwikkel. In hierdie verband kan gewys word op kulturele onderskeid as slegs een faktor waarmee ' $n$ regering rekening moet hou. Waar kulturele verskille ook saamhang met die bepaling van politieke gesag en ekonomiese welvaart, ontstaan 'n situasie wat maklik tot revolusie aanleiding kan gee (vgl maar die Biafraanse burgeroorlog in die sestigerjare).

Die gevare wat diepgaande sosiale stratifikasie kan inhou, spreek duidelik genoeg uit die Franse Revolusie van 1789. Interessant is egter die feit dat die staat met 'n sosiale ordening van geringe oorvleueling deeglik kennis moet neem van die aspirasies en vooruitskouinge van veral die sogenaamde 'middelklas' (akademici, skrywers, ens). As die leierselement van die breë volksmassa, speel hierdie groep 'n belangrike rol. Hulle is uiteraard meningsvormers, en in ' $\mathrm{n}$ ordelike bestel kan dié groep 'n positiewe bydrae tot die evolusionêre ontwikkeling van 'n land speel.

\footnotetext{
* Lt. Kdr. E.M. Meyers, MA HOD is verbonde aan die Militêre Informasieburo van die SAW
}

\section{Bibliografie: Boeke}

Jean Baechler, Revolution. Key Concepts in the Social Sciences, Basil Blackwell, Oxford, 1970.

Carleton Beals, The Nature of Revolution, Thomas Y 'Crowell Company, New York, 1969.

David V J Bell, Resistance and Revolution, Houghton Miflin Company, Boston, 1973. 
Crane Brinton, The Anatomy of Revolution, Vintage Books, New York, 1952. Katherine Chorley, Armies and the Art of Revolution, Beacon Press, Boston, 1973

Harry Eckstein (red), Internal War. Problems and Approaches, the Free Press of Glencoe, London, 1964.

John Ellis, Armies in Revolution, Croom Helm, London, 1973

George A. Kelly en Clifford W. Brown (reds), Struggles in the State: Sources and Patterns of World Revolution, John Wiley and Sons, Inc. New York.

Gustave Le Bon, The French Revolution and the Psychology of Revolution, Transaction Books, New Brunswick (USA), 1980.

Carl Leiden en Karl M. Schmidt (reds), The Politics of Violence. Revolution in the Modern World, Prentice Hall, Inc., Englewood Cliffs, N.J., 1968.

William Lutz en Harry Brent (reds), On Revolution, Withrop Publishers, Inc. Cambridge, 1971.

Ronald Matthews, African Powder Keg. Revolt and Dissent in six Emergent Nations, The Bodley Head, London, 1966.

Raymond M. Momboisse, Blueprint of Revolution. The Rebel, the Party, The Techniques of Revolt, Charles C. Thomas, Springfield, Illinois (USA), 1970.

Clifford T. Paynton en Robert Blackley (reds), Why Revolution?, Schenkman Publishing Company, Inc., Cambridge, 1971.

Gilbert Phelps, Latin America, British Broadcasting Company, London, 1965

Alvin Toffler, Future Shock, Pan Books, London, 1970.

Alvin Toffler, Third Wave, Collins, London, 1980.

\section{Tydskrifte}

R. Burt, "Power and the Peacock Throne: Iran's Growing Military Strength", The Round Table. Okt 1975

G. Connell-Smith, "Castro's Cuba in World Affairs, 1959-79", The World Today, Vol 35 No 1, Jan 1979.

B. Furlonger, "Cuba and Africa - Guevara's Ghost Pipes the Tune", Pacific Defence Reporter, 13 Okt 1978.

V. Izmailov, "Prelude to the Great October Revolution", Soviet Military Review, no 1, Jan 1977.

"Iran: The Sick Man of the Gulf", Armed Forces Journal International, Vol 118 No 3, Nov 1980

C. Landman, "Die Ideologie van Sowjet-Imperialisme", Departement van Buitelandse Sake, Aug 1982.

G. Russell, "Revolution Devouring Its Own", Time, 27 Sept 1982

L. Rust, "Die Implikasies van die Iraanse Rewolusie in Nasionale, Regionale en Globale Verband", Die Wêreld in Oënskou, Jaargang 17 Nos 6 en 7.

"The October Days", Soviet Military Review, (supplement) No 10, Okt 1977.

G.F. Treverton, "Cuba after Angola", The World Today, 1/77, 6 Mei 1977.

"The Time Factor in a Revolutionary War", Issup: Bulletin, 3/82, 30 Aug 1982

\section{Verwysings}

1. Bell, David V G, Resistance and Revolution, Houghton Miffin Company, Boston, 1973, p 7.

2. Le Bon, Gustave, The French Revolution and the Psychology of Revolution, Transaction Books, New Brunswick (USA), 1980, p 25.

3. Bell, op cit, $p 9$.

4. Ibid.

5. Toffler, Alvin, Future Shock, Pan Books, London and Sydney, 1970, p 359 .

6. Kelly, George A. en Brown, Clifford W (reds), Struggles in the State: Sources and Patterns of World Revolution, John Wiley and Sons Inc, New York, $\mathrm{p} 32$.

7. Le Bon, op cit, 054

8. Leiden, Carl en Schmidtt, Karl M. (reds), The Politics of Violence: Revolution in the Modern World, Prentice hall, Inc., Englewood Cliffs, N.J., 1968, p 9.

9. Paynton, Clifford T en Blackley, Robert (reds), Why Revolution? Theories and Analyses, Schenkman Publishing Company, Inc. Cambridge, 1971, 059.

10. Kelly en Brown, op cit, $p 96$.

11. Le Bon, op cit, p 29.

12. Lutz, William en Brent, Harry (reds), On Revolution, Winthrop Publishers, Inc., Cambridge, 1971, p 143.

13. Kelly en Brown, op cit, $p 150$

14. Paynton en Blackely, op cit, p 129; Kelly en Brown, op cit, $p 170$.

15. Kelly en Brown, op cit, p 150; Paynton en Blackley, op cit, p 177.

16. Lutz en Brent, op cit, $p 69$.

17. Ibid; Paynton en Blackley, op cit, p 273.

18. Paynton en Blackley, op cit, p 18

19. Ibid, p 103

20. Kelly en Brown, op cit, p 91

21. Paynton en Blackley, op cit, $p 180$.
22. Momboisse, Raymond M., Blueprint of Revolution: The Rebel, The Party, The Techniques of Revolt, Charles C. Thomas, Springfield Illinois (USA), $1970, p 19$

23. Beals, Carleton, The Nature of Revolution, Thomas $Y$. Crowell Company, New York, 1969, p 14.

24. Paynton en Blackley, op cit, p 105

25. The Time Factor in a Revolutionary War, Issup: Bulletin, 5/82, 30 Aug 1982, p 1.

26. Beals, op cit, $p 3$.

27. Ibid, p 8.

28. Momboisse, op cit, pp 11, 12

29. Leiden en Schmidt, op cit, p 10; Beals, op cit, p 8.

30. Paynton en Blackley, op cit, $p 88$.

31. Le Bon, op cit, $p 38$.

32. Schmidt en Leiden, op cit, $p 14$

33. Richards, Denis, An Illustrated History of Modern Europe 1789 - 2945 , Longmans, London, 1938.

34. Le Bon, op cit, p 64 .

35. Eckstein, Harry (red), Internal War: Problems and Approaches, The Free Press of Glencoe, Collier-Macmillan Limited, London, 1964, D 185.

36. Kelly en Brown, op cit, p 286.

37. Le Bon, op cit, p 139; Paynton en Blackley, op cit, p 88.

38. Richards, op cit, $\mathrm{p} 3$.

39. Eckstein, op cit, p 185

40. Brinton, Crane, The Anatomy of Revolution, Beacon Press 1952, p 31.

41. Paynton en Blackley, op cit, p 129.

42. Brinton, op cit, $\mathrm{p} 31$.

43. Richards, op cit, $\mathrm{p} 8$

44. Ibid, pp 5-8; Le Bon, op cit, pp 154, 155

45. Le Bon, op cit, $\mathrm{p} 64$.

46. Chorley, Katherine, Armies and the Art of Revolution, Beacon Press, Boston, 1973, p 138.

47. Le Bon, op cit, $p 29$

48. Ellis, John, Armies in Revolution, Croom Helm, London, 1973, p 89.

49. Le Bon, op cit, p 152.

50. Kelly en Brown, op cit, $p 98$.

51. Le Bon, op cit, p 52.

52. Ibid, p 64 .

53. Beals, $O p$ cit, $p 65$

54. Le Bon, op cit, $p 195$.

55. Momboisse, op cit, $\mathrm{p} 37$

56. Le Bon, op cit, p 264.

57. Beals, op cit, p 79; Le Bon, op cit, p 262

58. Kelly en Brown, op cit, p 286.

59. Beals, op cit, $p 125$

60. Brinton, op cit, $p 30$

61. Kelly en Brown, op cit, p 330

62. Ellis, op cit, $p 169$

63. Beals, op cit, $p 14$

64. Paynton en Blackley, op cit, p 184

65. Ibid, p 177

66. Leiden en Schmidt, op cit, p 42; Paynton en Blackley, op cit, p 184

67. Kelly en Brown, op cit, p 77.

68. Die Ideologie van Sowjet-Imperialisme, Lesing deur Departement van Buitelandse Sake, Aug 1982, p 5.

69. Beals, op cit, $p 127$.

70. The October Days, Soviet Military Review (supplement), no 10, Okt 1977, p 7.

71. Beals, op cit, $p 14$

72. Chorley, op cit, $p 147$

73. Eckstein, op cit, $\mathrm{p} 201$

74. Brinton, op cit, p 256.

75. Die Ideologie van Sowjet-Imperialisme, op cit, $p 5$.

76. Burt, Richard, "Power and the Peacock Thrown: Iran's Growing Military Strength", The Round Table, Okt 1975, pp 350; 352, 355

77. Ibid, 0351

78. Iran: The Sick Man of the Gulf. Armed Froces Journal International, vo 118 , no 3, Nov 1980, p 53.

79. Rust, Leno, "Die Implikasies van die Iraanse Rewolusie in Nasionale, Regionale en Globale Verband", Die Wêreld in Oënskou, Jaargang 17 No 7, 0147

80. Russel, George, "Revolution Devouring Its Own", Time, 27 Sept 1982 p 18.

81. Rust Leno, "Die Implikasies van die Iraanse Rewolusie in Nasionale, Regionale en Globale Verband", Die Wêreld in Oënskou, Jaargang 17, No 6,0113

82. Ibid, $p 118$

83. Ellis, op cit, p 217; Lutz en Brent, op cit, p 142

84. Ellis, op cit, p 236 . 
85. Lutz en Brent, op cit, $p 142$.

86. Ibid.

87. Ibid, $p 143$

88. Eckstein, op cit, p 209; Phelps, Gilbert, Latin America, British Broadcasting Corporation, London, 1965, p 71.

89. Beals, op cit, $p 108$

90. Leiden en Schmidt, op cit, $p 135$

91. Ibid, p 183; Paynton en Blackley, op cit, p 59.

92. Leiden en Schmidt, OD cit, 0203

93. Furlonger, Brian, "Cuba and Afrika - Guevara's Ghost Pipes the Tune", Pacific Defence Reporter, 13 Okt 1978.

94. Beals, op cit, $\mathrm{p} 232$

95. Furlonger, op cit.

96. Ibid.

97. Pacific Defence Reporter Annual Reference Edition 1980-1, p 79

98. Kelly en Brown, op cit, pp 120, 121

99. Momboisse, op cit, p 309 .

100. Kelly en Brown, op cit, pp 507.

101. Toffler, Future Shock, op cit, p 172.
102. Ibid, p 238.

103. Ibid, p 337 .

104. Ibid, p 359

105. Toffler, Alvin, The Third Wave, Collins, London, 1980, p 20.

106. Ibid, p 453

107. Ibid, p 33

108. Ibid, p 354.

109. Kelly en Brown, op cit, p 169

110. Brinton, op cit, p264.

111. Ibid.

112. Ibid, p 265

113. Ibid.

114. Ibid.

115. Momboisse, op cit, pp 12, 14

116. Paynton en Blackley, op cit, p 105; Momboisse, op cit, p 21.

117. Paynton en Blackley, op cit, p 105.

118. Ibid, p 106

119. Ibid, $p$ 107 